\title{
Pore Pressure Prediction of an Oil-Field in Part of the Niger Delta Basin, Nigeria
}

\author{
${ }^{*}$ CHIAZOR FI; BEKA FT
}

\author{
Department of Geology, Faculty of Science, University of Port Harcourt, Port Harcourt, Nigeria
}

*Corresponding Author Email: yoursfin@yahoo.com

\begin{abstract}
In this study, overpressure prediction was carried out for ten oil wells in a selected oil-field in part of the Niger Delta basin, Nigeria. The age of key stratigraphic surfaces (9.5Ma-65Ma), depth, thickness and sedimentation rates from well logs and biostratigraphic data was used to build pressure models. The generated pressure model was calibrated using key petrophysical, geochemical and pressure data until a match was achieved. The model predicts occurrence of localized under-compaction driven overpressure at about $11.5 \mathrm{Ma}$. From the results, the onset of overpressure is likely at depths beyond $14,760 \mathrm{ft}$ which corresponds to the $11.5 \mathrm{Ma}$ marker shales, while fluid pressures ranging from $0.53-0.7 \mathrm{psi} / \mathrm{ft}$ are estimated at $15,744 \mathrm{ft}$ and hard overpressures ranging from $0.7-0.9 \mathrm{psi} / \mathrm{ft}$ are likely at depths beyond $19,680 \mathrm{ft}$ which corresponds to the $12.8 \mathrm{Ma}$ marker shales. This study provides good prediction on the occurrence of pressure in the deeper prospect.
\end{abstract}

DOI: https://dx.doi.org/10.4314/jasem.v23i12.28

Copyright: Copyright (C) 2019 Chiazor and Beka. This is an open access article distributed under the Creative Commons Attribution License (CCL), which permits unrestricted use, distribution, and reproduction in any medium, provided the original work is properly cited.

Dates: Received: 30 November 2019; Revised: 20 December 2019; Accepted: 23 December 2019

Keywords: overpressures, under-compaction, sedimentation rate, marker shales, deeper prospect

Predicting pore pressure is critical especially for deeper prospects of some economic fields in the Niger Delta Basin (Figure 1) A good understanding of overpressure distribution and formation strength in an area is very important for the safe and cost effective drilling in an over pressured environment. Earlier, overpressure prediction was based on empirical data analysis from well logs and seismic data (Eaton 1972; Bower 2002). Eaton proposed an empirical equation to quantify the pore pressure using sonic transient time and formation resistivity or dc-exponent. Bower used sonic velocity and empirically determines the vertical effective stress, which is then subtracted from the overburden to determine the pore pressure. In the Niger Delta Overpressure prediction was done using empirical data from pressure measurements, drilling data and sonic log data (Daukoru, 1973). Adeoye (2001) used existing well pressure data and empirical method similar to that of Krusi (1990) to generate various regional overpressure distribution maps of the Niger Delta. But such approach has limitations in constrained data setting and static nature. Simulating a basin is now a predictive technique in the exploration plans of most oil companies since it presents a continuous, critical and robust view of events that include deposition of sediment, compaction, fluid flow, and heat transfer, maturation of source rock, migration, accumulation and expulsion of petroleum. Apart from giving explorers the platform to model the evolution of a basin in a definite pattern, overpressure can equally be predicted. The objective of this paper is to estimate and model the overpressure developments across ten oil wells in a selected field in the Niger Delta basin, Nigeria using the basin modeling approach.

\section{MATERIALS AND METHODS}

The following materials were used in predicting the overpressures developments in the study area Location and Geology of the study area: The study area is located about $40 \mathrm{~km}$ south west of Port Harcourt, which is part of the Coastal Swamp depobelt of the eastern Cenozoic Niger Delta. (Fig.1). Ten wells were used for the research. Sediment deposition in this area started in early Miocene times. The location coordinates are longitudes $6046^{\mathrm{ec}}-6053^{\mathrm{ec}} \mathrm{E}$ and latitudes $4028^{\mathrm{ee}}-4032^{\mathrm{ee}} \mathrm{N}$ and cover a total area of about $154 \mathrm{Km}^{2}$ with a perimeter of about $50 \mathrm{~km}$.

The tectonic setting of the Niger Delta basin has been attributed to the divergence of the African and South American Plates and creation of Southern Atlantic. It has also being proposed that a triple junction developed (Burke et al., 1971). While Grant (1971) suggests an RRF (ridge-ridge fault) triple junction. Burke et al., (1971) and Wright, (1976) proposed that the origin of this basin began shortly after the development of an RRR (ridge-ridge-ridge) triple junction system. The inactive rift of this triple structure is the Anambra-Benue rift valley where the 
oceanic crust was inactive. The rivers depositional centers moved seawards and in consequence, the coastal plain deposits became progressively younger in that direction.

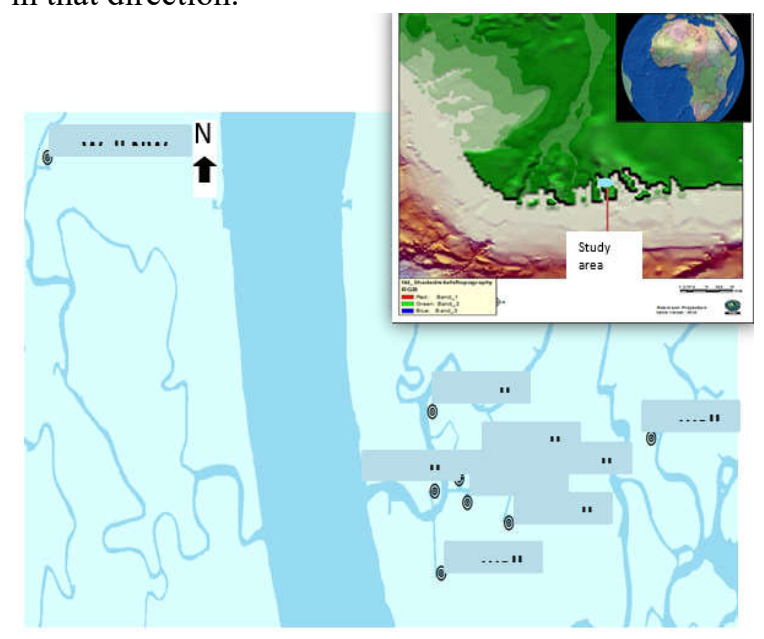

Fig 1: Map of study location (inset) and location of ten wells across the field

The Niger Delta complex has undergone little deformation at the upper region but the subsurface had experienced major deformed by large scale synsedimentary features such as growth faults, rollover anticlines and diapers. Sediment deposition in this area started in early Miocene times. The Niger Delta stratigraphic sequence of holomarine shales (Akata Formation) and lower coastal plain sand-shale alternation (Agbada Formation and the upper coastal plain sands, Benin Formation) are recognized throughout the study area. The sedimentary succession comprises of lithology of the Tertiary massive Akata shales grading through mixed sands and shales of the Agbada Formation into the massive sands of the Benin Formation.

Suites of wire line logs: This includes Gamma ray log, resistivity logs, neutron density logs, porosity and sonic logs. Gamma ray log was used for the evaluation of shale volume content that was used in building the stratigraphic column in (fig.4) which controls the development of pressure on the1D pore pressure model in figure 4 . The bulk density log combined with the neutron porosity log was used to determine gas and oil zones. Overpressure zones are linked with hydrocarbon zones in the formation. Bulk density log and sonic log was used to calibrate the measured calculated bulk density and sonic velocity generated from the pressure model in figure 5

Secondary data: This includes the biostratigraphic data, bathymetric data. Biostratigraphic data was used to identify the time the formations was deposited throughout geologic time. It was used in constructing the stratigraphic column in figure 4 .

Paleobathymetric environment of deposition was used to estimate the water depth in the burial history curve in figure 3.

The $3 D$ seismic volume: Seismic was used in generating the stratigraphic framework of the study area as seen in figure 2 .

RFT Pressure: RFT Pressure was used to calibrate the pressure model( in the 1D pore pressure model) (fig. 4)

Bottom hole temperature: Bottom hole temperature was used in calibrating the corrected measured temperature in the 1D pore pressure model. (fig.4)

Vitrinite reflectance: Vitrinite reflectance is a maturity index that was used to calibrate the generated source rock maturity history in the 1D pore pressure mode (fig.4). The methodology adopted for this study is basin modeling after Hantschel and Kauerauf (2009); Waples et al. (1992); Welte et al. (1988) and Tissot et al. (1987) was used in predicting the pressure history in the study area. The three major stages involved in this model building include the burial history curve, thermal model, numerical simulation stage. The burial history stage, assess the geologic history of rock layers through the use of geologic cross sections. . Plotting cumulative thickness of layers estimated from gamma ray logs against age $(9.5 \mathrm{Ma}$ to $65 \mathrm{Ma})$ gotten from biostratigraphic data results in a set of curve that explains the stratigraphy of the area.

Thermal model evaluates the temperature history of stratigraphic layers in a basin. Thermal model was generated using top boundary conditions (surface water depth and temperature) and bottom boundary condition (crustal thickness). Water depth was estimated using paleobathymetry from biostratigraphic data.

The model generated was calibrated using actual measured data which includes density, sonic, porosity, permeability, RFT pressures, Bottom Hole Temperature and vitrinite reflectance until a match was achieved. Typically the sonic velocity decreases (transit time increases) and the resistivity decreases as an undercompacted zone is entered. The increase in transit time and resistivity as an overpressured zone is entered is often referred to as a $\log$ "reversal". Recognition of the top of the overpressures relies on identification of the point at which the log response deviates from a normal compaction trend. 


\section{RESULTS AND DISCUSSIONS}

From the 1D Pore pressure model for well 005 the deepest well (fig. 4), the pressure model showed a deviation from the hydrostatic at about $14760 \mathrm{ftss}$ $(4500 \mathrm{M})$ and a marked high sedimentation rate at the same depth in the stratigraphic column that corresponds to the $11.5 \mathrm{Ma}$ marker shale. Fluid pressures ranging from $0.53-0.7 \mathrm{psi} / \mathrm{ft}$ is estimated at $15,744 \mathrm{ftss}(4550 \mathrm{~m})$ and hard overpressure ranging from $0.7-0.9 \mathrm{psi} / \mathrm{ft}$ is likely at depths beyond $19,680 \mathrm{ftss}$ $(6060 \mathrm{~m})$ which correspond to the $12.8 \mathrm{Ma}$ marker shale.

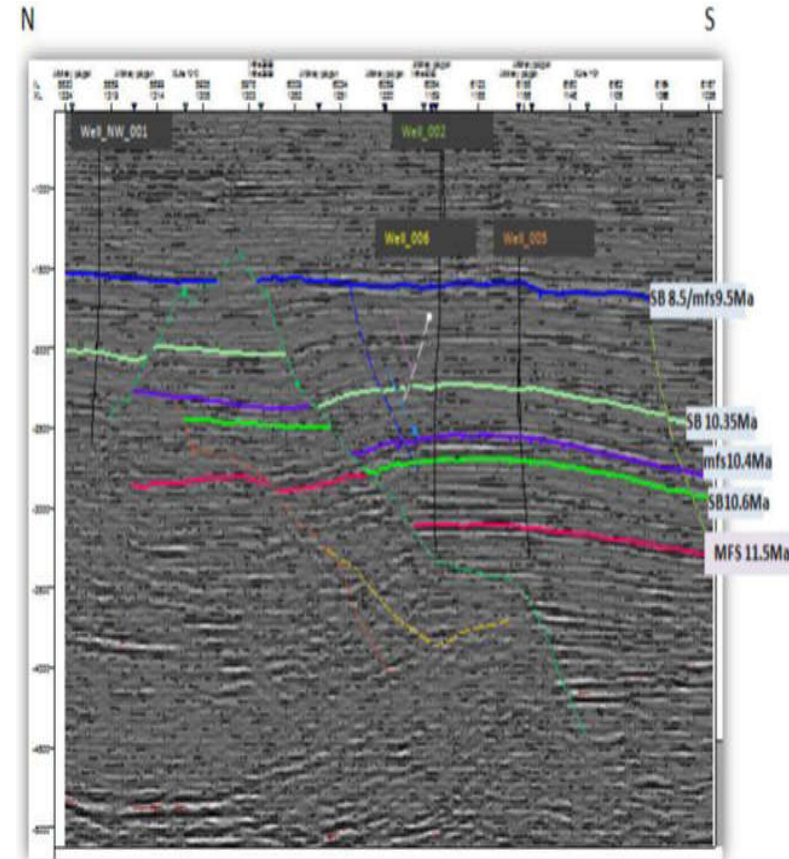

Fig 2. Stratigraphic framework for the study area

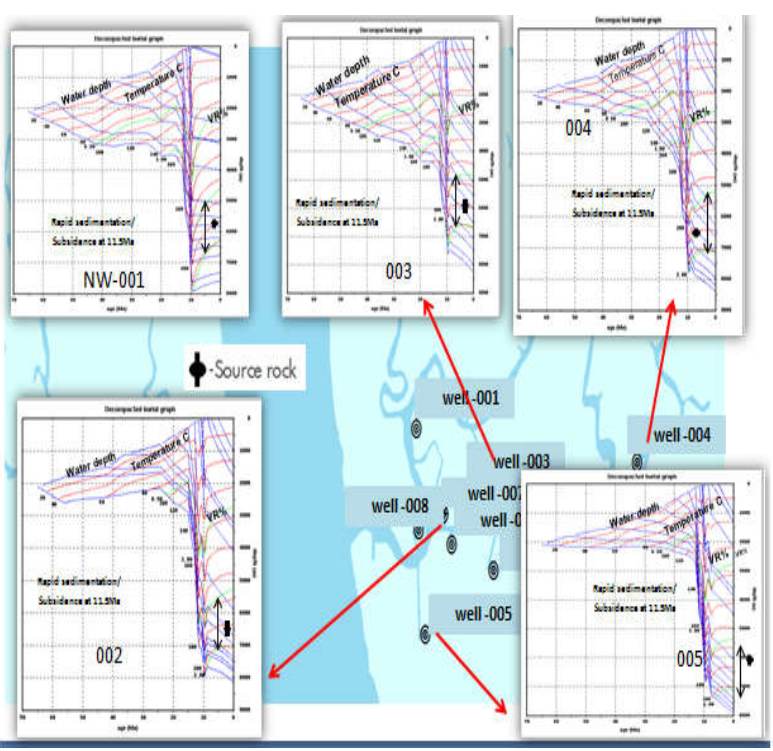

Fig 3: Generated cauldron burial history curve

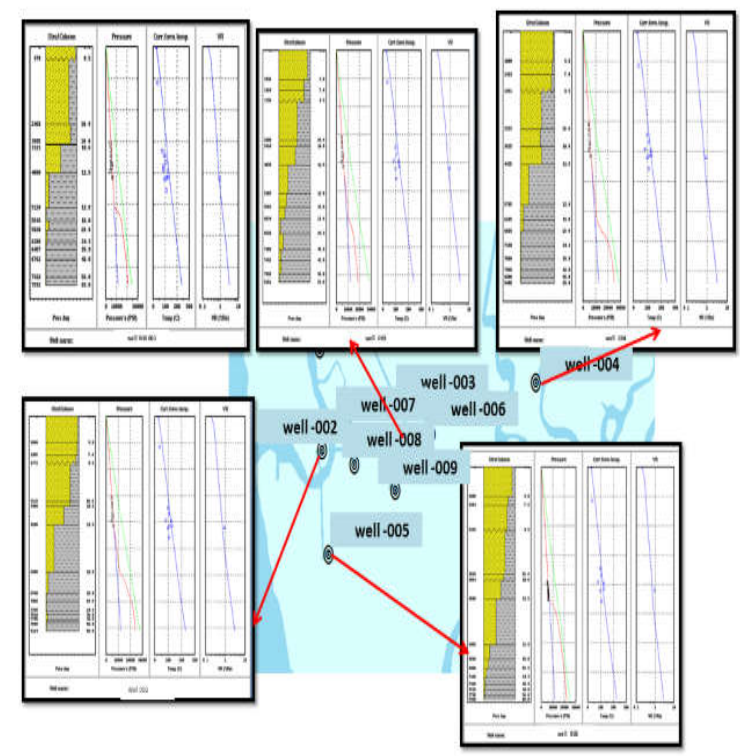

Fig 4: 1D Pore pressure model. In the pressure model, the blue lines are the hydrostatic pressure, green lines are the lithostatic pressure and the red lines are the predicted pore pressure. The black dots are the RFT pressures that are used to calibrate the pressure model. In the thermal model (corrected formation temperature) the blue line is the generated formation temperature, the blue dots are the bottom hole temperature used to calibrate the model. In the maturity model(VR), the blue lines are the modelled vitrinite reflectance and the blue dot is the actual vitrinite reflectance for that well.

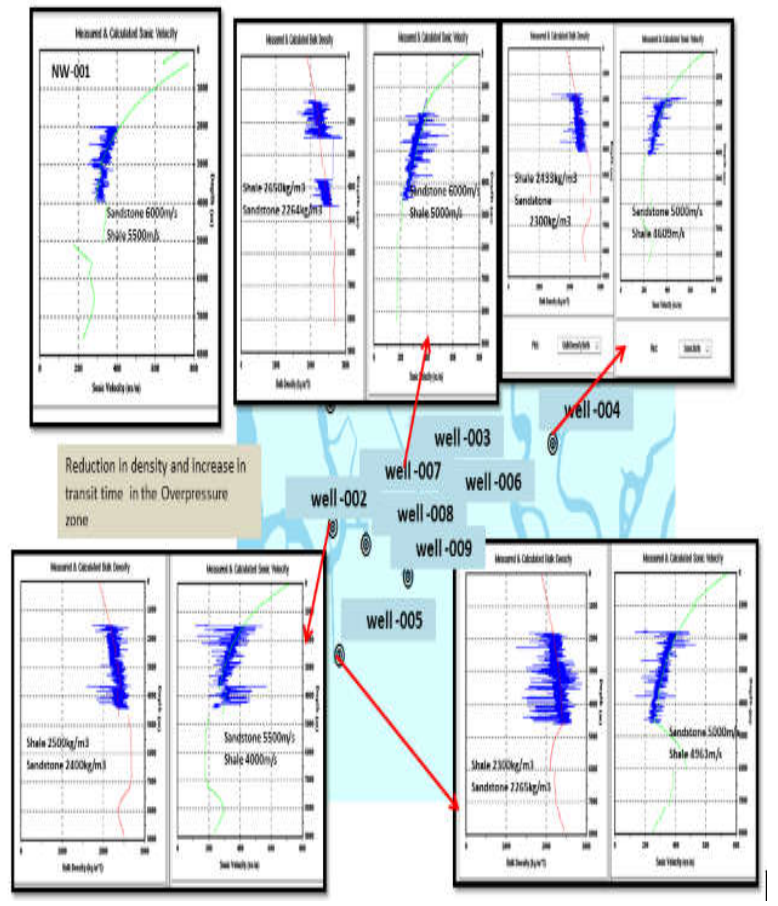

Fig 5: Calibration using Bulk density and sonic log. In the measured and calculated bulk density, the red lines is the modeled bulk density while blue curves are the actual bulk density. In the measured and calculated sonic log, the green lines are the modeled transit time while the blue curves are actual transit time form sonic log. 


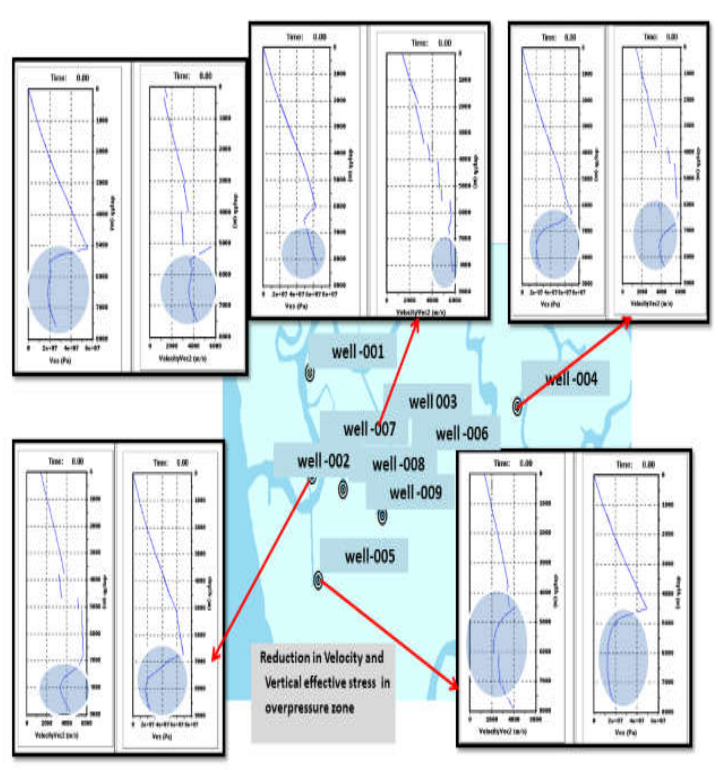

Fig 6: Velocity and vertical effective stress calibration

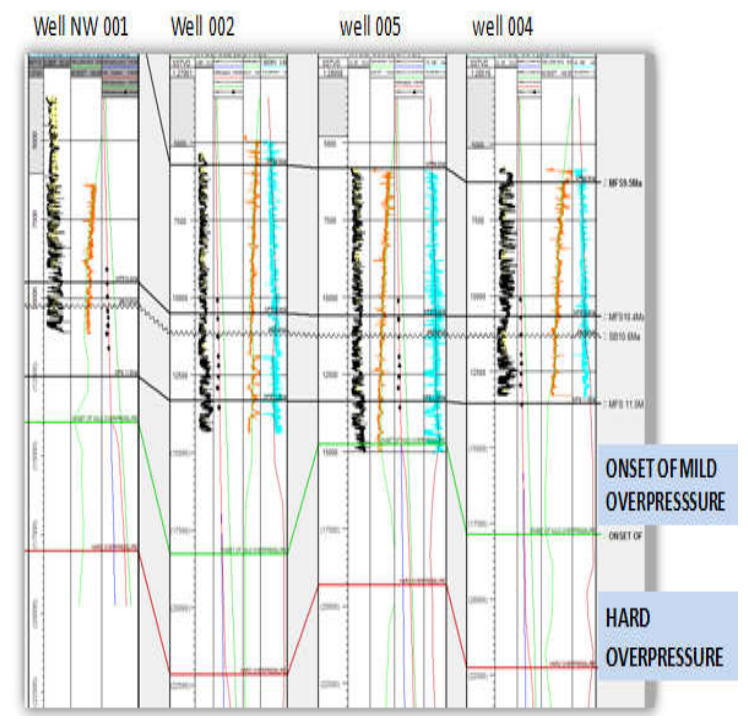

Fig 7: Onset of overpressure distribution on well section

From the calculated density and sonic log in Fig. 5, the density becomes lighter away from the usual trend of increase or heavier density with increasing depth in the overpressured zone and the Interval transit time in the sonic $\log$ increases away from the usual trend of decreasing or slower interval transit time with depth. In the overpressured zone. Porosity increases away from the usual decrease in porosity with depth while permeability reduces as well in the overpressure zone. The Vertical effective stress and velocity as seen in Fig. 6 also reduced away from the usual increase with depth in the over pressured zone.. This agrees with the pore pressure prediction made by Hottmann and Johnson (1965) using shale properties from well log data. This prediction is based on any deviation in the measured properties from its normal trend line. In Well-004 (Figs. 4), the model predicts that likely mild overpressure could occur beyond $7868 \mathrm{ftss}(5447.5 \mathrm{~m})$ with fluid pressure of $9600 \mathrm{psi}(0.54 \mathrm{psi} / \mathrm{ft})$ at $11.5 \mathrm{Ma}$ and hard overpressure likely at $21320 \mathrm{ftss}(6500 \mathrm{~m})$ with fluid pressure $15000 \mathrm{psi}(0.7 \mathrm{psi} / \mathrm{ft})$ at $15 \mathrm{Ma}$. The overpressure prediction for other wells across the field is displayed in fig. 7. Overpressure zones were also estimated beyond depths penetrated

Conclusions: The Pore pressure model reveals that high pressure zones are marked with high sedimentation rates and deviation from the normal trend of petrophysical properties. Finally, the results of this study forms the basis for developing an accurate and robust pore pressure prediction strategy and can be applied to other sedimentary basins in predicting over pressures.

Acknowledgment: The authors acknowledge Shell Petroleum Development Company (SPDC), for the data and facility that were used in this work. We also appreciate the support of the industry supervisors, Dr. Jurgen Frielingdolf and Obilaja Segun

\section{REFERENCES}

Bell, DW (2002). Velocity Estimation for PorePressure Prediction. In Huffman AR; Bowers, GL (ed) Pressure regimes in sedimentary basins and their prediction: AAPG Memoir 76, p. 177215.

Bowers, GL (2002) Detecting high overpressure: The Leading Edge, v. 21, p. 174-177.

Eaton, BA (1972) Graphical method predicts geopressures worldwide: World Oil. 182. 51-56.

Grant, NK (1971) South Atlantic, Benue trough and Gulf of Guinea Cretaceous triple junction: Bull. Geol. Soc. Am. 82, 2295-2298.

Hantschel, T; Kauerauf, AI (2009) Fundamentals of Basin Modeling, Springer Verlag, Berlin, Germany, 476pp

Hottmann CE; Johnson RK (1965) Estimation of formation pressures from $\log$ derived shale properties. Journal Petroleum Technology 17: 717-722.

Short, KC; Stauble, AJ (1967) Outline of Geology of Niger Delta. American Association of Petroleum Geologists Bulletin v. 51, p. 761-779. 
Tuttle, MLW; Brownfield, ME; Charpentier, RR (1990) Tertiary Niger Delta (Akata-Agbada) petroleum System (No. 701901), Niger Delta province. Cameroon, and Equatorial Guinea, Africa: U.S. Geological Survey Open File report 99-50H, p.1-13.
Ungerer, PJ; Burrus, B; Doligez, P; Chenet, Y; Bessis, F (1990) Basin Evaluation by integrated twodimensional modeling of heat transfer, fluid flow, hydrocarbon generation and migration. $\mathrm{Am}$ Assoc. Petrol. Geol. Bull. 74,309 - 355

Welte, DH; Yalcin, MM (1988) Basin modeling, a new comprehensive method in petroleum geology: Advances in Organic Geochemistry. 13. 141-151. 